\title{
REDESIGN OF POLITICAL PARTY DISPUTE SETTLEMENT INSTITUTIONS: A COMPARATIVE STUDY OF INDONESIA AND KENYA
}

\author{
Alwan Sultan*, Student Doctoral of Law \\ Safa'at Rachmad, Professor of Law \\ Sihabudin, Widiarto Aan Eko, Associate Professors \\ University of Brawijaya, Malang, Indonesia \\ *E-mail: sul alwan3@yahoo.com
}

\begin{abstract}
Currently, there are at least three institutions that resolve political party disputes in Indonesia, namely the political party court or other designations formed by political parties, through a lawsuit to the district court after first making efforts to resolve it at the party court and through a lawsuit to the state administrative court by the party, that object to the Decree of the Minister of Law and Human Rights against the ratification of the new management or changes to the party constitution. Such conditions have led to a protracted and ineffective resolution of party disputes. The State of Kenya has implemented the settlement of political party disputes through a one-door channel, namely The Political parties Disputes Tribunal which is part of the judicial power system. The Political parties Disputes Tribunal is very effective in resolving political party disputes in the State of Kenya. In order to make the settlement of political party disputes effective in Indonesia, it is necessary to redesign the one-stop political party settlement institution, namely by establishing a court that is special in the judicial power system.
\end{abstract}

\section{KEY WORDS}

Disputes, political parties, party special courts.

One of the characteristics of a rule of law is a state that is democratic in nature and power is limited through general elections. ${ }^{1}$ Indonesia is a state of law and sovereignty is in the hands of the people which are run according to the law. The rule of law is a state that stands on the law guaranteeing justice for its citizens. ${ }^{2}$ The rule of law must certainly be supported by a democratic system because there is a correlation between a constitutional state based on the constitution and the principle of popular sovereignty which is implemented with a democratic system. ${ }^{3}$ However, democracy without the rule of law will certainly lose its form and direction. And vice versa, law without democracy will lose its meaning. ${ }^{4}$ According to Jimly Asshiddiqie, a legal state that is based on a democratic system can be called a democratic legal state (demokratische rechtsstaat). ${ }^{5}$

Political parties are the main actors in democracy that connect the people with the state and government. ${ }^{6}$ Especially at the level of electoral democracy and political democracy. ${ }^{7}$ The development of democracy has reduced the role of political parties in common life, especially in the life of the state. The development of democracy is very influential on the dynamics of the development of political parties. The higher the level of democracy, the more dynamic the development of political parties, especially the role of political parties.

Political parties have an important role in determining state policy. ${ }^{8}$ Political parties are positioned as a support for democracy for government stability. ${ }^{9}$ Political parties are also a

\footnotetext{
Jimly Asshiddiqie, Konstitusi dan Konstitusionalisme Indonesia, Konstirsi Press, Jakarta, 2005, hl. 154-162.

${ }^{2}$ Moh. Kusnardi dan Bintan R. Sargih, IImu Negara, Cetekan ke-2 Penerbit Gaya Media Pranata, Jakarta, 1988, hal. 126.

${ }^{3}$ Montoha, Negara Hukum Indonesia Pasca Perubahan UUD 1945, Penerbit Kaukaba, Yogyakarta, 2013, hlm. 3.

${ }_{5}^{4}$ Ridwan HR, Hukum Adinistrasi Negara, UII-Press, Yogyakarta, 2002, hal. 7.

5 Jimly Asshiddiqie, Kapita Selekta Teori Hukum Kumpulan Tulisan Tersebar, FH-UI, Jakarta, 2000, hal.141-144.

${ }^{6}$ H.A Muktie Fadjar, Parpol Dalam Perkembangan Ketatanegaraan Indonesia, In-Trans Publising, Malang, 2008, hal. 16-17.

Agus Riwanto, Hukum Partai Politik dan hukum Pemilu Di Indonesia: Pengaruhnya Terhadap Penyelenggaraan Pemilu Berkualitas dan Sistem Pemerintahan Presidensial Efektif, Thafa Media, Yogyakarta, 2016, hlm. 34.

${ }^{8}$ Oly Viana Agustine, Redesain Mekanisme Konstitusional Pembubaran Partai Politik: Kajian Perbandingan Indonesia dan Jerman, Jurnal NEGARA HUKUM: Vol. 9, No. 2, November 2018, hlm. 122

${ }^{9}$ Firdaus, Constitutional Engineering Desain Stabilitas Pemerintahan Demokrasi dan Sistem Kepartaian, Yrama Widya, Bandung, 2015, hlm. 12.
} 
forum for citizens to channel their aspirations and political interests, either directly involved as administrators or as sympathizers. ${ }^{10}$ The emergence of greater expectations of the party so that political parties inevitably have to appear prime so that they can answer, respond to the expectations of their constituents.

Political parties as organizations that have a central function and role in running the wheels of democracy by producing leaders in the legislative and executive institutions, both at the center and in the regions, are not uncommon for internal disputes to occur within political parties. ${ }^{11}$ These disputes can arise from the expectations of party cadres to get positions in the party. Party disputes relating to issues of rights and/or interests between members of political parties, disputes over rights and/or interests between members of political parties and political parties, up to the emergence of disputes over the management of political parties which are usually marked by dualism in the management of political parties. Competition within the internal party is unavoidable because the number of party cadres with party administrators is more party cadres, while the functionaries are fewer.

Party disputes that occur need special attention, when unstable political parties will have implications for the running of the government. The need for a resolution of political party dispute resolution institutions considering that currently in Indonesia there are many institutions involved in resolving political party disputes, causing legal uncertainty. Thus, a more effective mechanism for resolving political party disputes is needed.

As an ingredient in the redesign of party dispute resolution institutions in Indonesia, a comparison of the State of Kenya will be described. The country of Kenya was chosen because based on the Political Parties Act in the State of Kenya, ${ }^{12}$ The resolution of party disputes has been carried out through a special state court (on court). The problem in this paper is how to regulate political party dispute settlement institutions in Kenya and how to redesign political party dispute settlement institutions in Indonesia to realize substantive justice.

\section{METHODS OF RESEARCH}

This research is a legal research with a socio-juridical type of research (socio-legal). Sociological juridical research based on normative legal science compares with the reality that occurs in the field (law in action). ${ }^{13}$ The approach used is comparative law, case studies, legislation approach and conceptual approach.

\section{RESULTS AND DISCUSSION}

Miriam Budiardjo defines a political party as an organized group whose members share the same orientation, values and desires. ${ }^{14}$ Meanwhile, Ali Safa'at stated that political parties are one of the embodiments of the right to freedom of association which is closely related to freedom of expression and freedom of thought and belief. ${ }^{15}$ Judging from the purpose of the formation of an organization oriented political parties can control power in the government so that the ideology, vision and mission as well as party programs can be used as a basis for exercising government power. ${ }^{16}$ Political parties are the only legitimate organizations to bring someone into the world of politics and power. ${ }^{17}$ The discussion of the party system cannot be

\footnotetext{
${ }_{11}^{10}$ Dwi Darojatun Patra Suwito, Aspek Hukum Perselisihan Internal Partai politik, Adhi Sarana Nusantara, Jakarta ,2017, hlm. 2.

11 Aris Rahmatdi dan Pan Mohamad Faiz, Gugatan Perdata Perbatan Melawan Hukum Dalam Perselisihan Partai Golongan Karya: Kajian Putusan Nomor 91?Pdt.G/2015/PN.Jkt.Utr, Jurnal YUDISIAL, Vol. 14 No. 1 April 2021, hlm. 80.

Lihat, The Political Parties Act, 11 of 2011, Part V. The Political parties Disputes Tribunal Kenya. http://kenyalaw.org/kl/fileadmin/pdfdownloads/Acts/PoliticalPartiesAct.pdf. Diakses 2 Juni 2021.

${ }_{13}^{13}$ Mukti Fajar, Yulianto Ahmad, Dualisme Penelitian Hukum Normatif dan Empiris. Yogyakarta: Pustaka Pelajar, 2013, hlm. 46-47.

${ }_{14}$ Miriam Budiardjo, Dasar-Dasar Ilmu Politik, PT. Gramedia Pustaka Utama, Jakarta, 2008, hlm.159.

${ }^{15}$ Muchamad Ali Safa'at, Pembubaran Partai Politik Pengaturan dan Praktik Pembubaran Partai politik dalam Pergulatan Republik, Rajawali Pers,

Depok, 2017, hlm. 3.

${ }_{16}$ Mustafa Lutfi, M. Iwan Satriawan, Mustafa Lutfi dan M. Iwan Satriawan, Risalah Hukum Partai Politik di Indonesia, UB Press, Malang, 2016, hlm. 29.

${ }_{17}$ Laoly, Y. H. (2019). Manajemen sengketa partai politik, sebuah ikhtiar penataan kelembagaan politik di negeri demokrasi, Alvabet, Jakarta,

2019, hal. 71
} 
separated from the number of political parties that have major party power, so it is known that there are single party systems, two-party systems, and multi-party systems. ${ }^{18}$

The Republic of Kenya is a multi-party democratic country founded on the values and principles of democracy, popular participation, non-discrimination and protection of the marginalized. ${ }^{19}$ The existence of political parties is regulated in the Kenyan Constitution, Article 92 states:

Legislation on political parties. 92. "Parliament shall enact legislation to provide for: (a) the reasonable and equitable allocation of airtime, by State-owned and other specified categories of broadcasting media, to political parties either generally or during election campaigns; (b) the regulation of freedom to broadcast in order to ensure fair election campaigning; (c) the regulation of political parties; (d) the roles and functions of political parties; (e) the registration and supervision of political parties; (f) the establishment and management of a political parties fund; $(g)$ the accounts and audit of political parties; (h) restrictions on the use of public resources to promote the interests of political parties; and (i) any other matters necessary for the management of political parties". 20

The Kenyan Constitution provides signs as a requirement for the establishment of political parties as regulated in Article 91 of the 2010 Kenya Constitution, one of which is "abide by the democratic principles of good governance, promote and practice democracy through regular, fair and free elections within the party".

In addition to arrangements at the constitutional level, political parties in Kenya are regulated in The Political Parties Act, 2011 No. 11 of 2011 which has undergone several changes, the latest being the Political Party Law Number 14 of 2016 The Political Parties Act, 2011 explicitly emphasizes that the resolution of political party disputes is through the judiciary.

The position of The Political parties Disputes Tribunal in the Kenyan judicial system is within the Tribunal Courts. The types of party disputes that are resolved through this Tribunal include: (1) Disputes between members of political parties; (2) Disputes between members of political parties and political parties; (3) Disputes between political parties; (4) Disputes between independent candidates and political parties; (5) Disputes between coalition partners; and (6) Appeal based on the decision of the clerk based on this law. ${ }^{21}$

In principle, party disputes can be resolved through internal mechanisms, but if they are not resolved, the channel provided is The Political Parties Disputes Tribunal. ${ }^{22}$ Settlement of political party disputes through The Political parties Disputes Tribunal is a way to ensure the applicant gets a fair hearing and gets legal protection.

According to Adi Sulistiyono and Isharyanto, the independence of the court can be seen at least in three aspects, namely the independence of decision-making, personal independence and administrative independence. ${ }^{23}$ The judges for The Political parties Disputes Tribunal are appointed by the Judicial Services Commission. The presiding judges come from high court judges and 4 (four) member judges are required to have high integrity. ${ }^{24}$ In this aspect, it can be said that the judges of The Political Parties Disputes Tribunal are personally independent because they are not bound by the binding institution (patron-client). Personal independence has a big influence on the independence of decision making.

Likewise, from the aspect of administrative independence, The Political Parties Disputes Tribunal is part of the judicial power system, so the salaries and remuneration of the presiding judges and member judges, court employees are charged to the state budget. Payment of remuneration of court staff and court operations is included in the budget of the

\footnotetext{
${ }^{18}$ Agus Riswanto, Op. Cit, hlm. 36.

19 Pasal 4, Constitution Of Kenya, 2010, Nasional Council For Law Reforting KLR Kenya Lawa Reports. www.kenyalaw.org. Diakses 21 Agustus 2020.

${ }^{20}$ Pasal 92, Ibid.

${ }^{21}$ Pasal 40 Ayat (1), Ibid.

22 Pasal 40 Ayat (2), Ibid

${ }^{23}$ Adi Sulistiyono dan Isharyanto, Sistem Peradilan Di Indonesia Dalam Teori dan Praktik, Prenadamedia Group, Depok, 2018, hlm.39.

24 Lihat, The Political Parties Act, 11 of 2011, Part V. The Political parties Disputes Tribunal Kenya. http://kenyalaw.org/kl/fileadmin/pdfdownloads/Acts/PoliticalPartiesAct.pdf. Diakses 22 Agustus 2020.
} 
Judiciary to be allocated by the National Assembly. ${ }^{25}$ Thus, the judges of The Political Parties Disputes Tribunal are not administratively bound by other institutions.

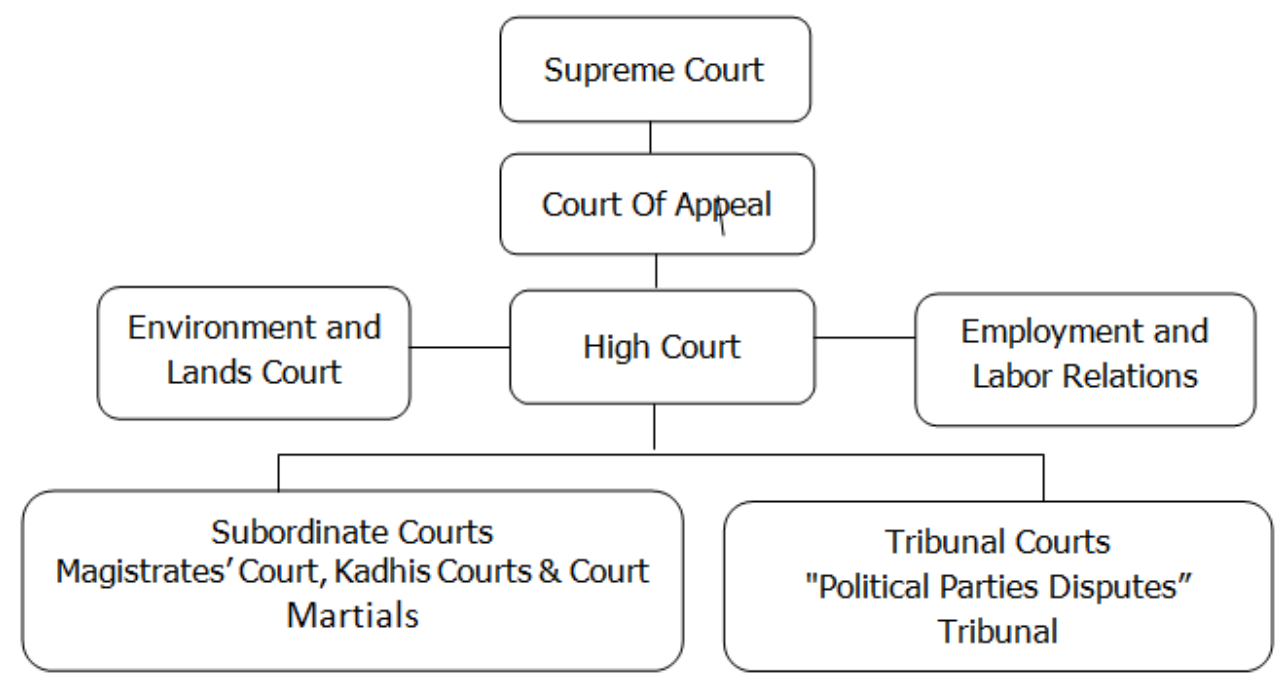

Figure 1 - The Structure of Judicial Power in the Republic of Kenya

The position of The Political Parties Disputes Tribunal is within the Tribunal Courts. The decision of The Political Parties Disputes Tribunal can be corrected/appealed to the High Court. Likewise, in stages, if you are not satisfied with the High Court's decision, an appeal to the Court of Appeal can be made and a final legal remedy to the Supreme Court.

At the implementation level, the role of The Political Parties Disputes Tribunal is very significant in dealing with political party disputes. This can be seen from the high number of cases submitted to The Political Parties Disputes Tribunal. However, the settlement through The Political Parties Disputes Tribunal can run effectively. This can be seen in the table below:

Table 2 - Number of Cases and Legal Efforts on Appeal in Kenya in 2017

\begin{tabular}{|l|l|l|l|l|}
\hline $\begin{array}{l}\text { Jumlah Perkara } \\
\text { (Complaint) }\end{array}$ & $\begin{array}{l}\text { Political Parties Dispute } \\
\text { Tribunal (PPDT) }\end{array}$ & $\begin{array}{l}\text { High Court } \\
\text { Decision }\end{array}$ & $\begin{array}{l}\text { Court of Appeal } \\
\text { Decision }\end{array}$ & $\begin{array}{l}\text { Supreme } \\
\text { Court }\end{array}$ \\
\hline 375 & 375 & 55 & 10 & - \\
\hline
\end{tabular}

Source: Secondary data processed from Website of The Judiciary Republic of Kenya.

Based on the table above, what is interesting is that of the 375 cases received, examined and decided by The Political Parties Disputes Tribunal, only 55 of the decisions of The Political Parties Disputes Tribunal were appealed to the High Court. Likewise, the cases decided by the High Court were only 10 cases that continued to appeal to the Court of Appeal. Meanwhile, the decision of the Court of Appeal can be accepted by the parties so that there is no longer any legal action against the Supreme Court.

One of the roles of the judiciary is to resolve disputes fairly with the principles of a simple, fast and low-cost trial in order to realize an effective and efficient judiciary. ${ }^{26}$ There are at least two aspects to measure the effectiveness of the court, namely, the procedural aspect and the judge's decision aspect in handling a case. The procedural aspects are related to transparency, access, and balance of the parties to be involved in the evidentiary process. ${ }^{27}$

\footnotetext{
${ }^{25}$ Lihat, Pasal 44, Ibid

${ }^{26}$ Indriati Amarini, Penyelesaian Sengketa yang Efektif dan Efesien Melalui Optimalisasi Mediasi Di Pengadilan, Jurnal Kosmik Hukum, Vol. 16, No. 2 Juni 2016 , hlm. 87.

${ }^{27}$ Muhamad Isnu, dkk, Membaca Pengadilan Hubungan Industraial Di Indonesia: Penelitain Putusan Mahkamah Agung Pada Lingkum Pengadilan Industrial 206-2013, Lembaga Bantuan Hukum Jakarta, 2014, hlm. v
} 
Settlement of political party disputes through The Political Parties Disputes Tribunal is very effective both from the procedural aspect and from the aspect of the judge's decision in handling cases. Although there are efforts to make corrections to the above courts, the numbers are small compared to the decisions that are immediately received by the disputing parties. This condition shows that the existence of a dispute resolution institution through the tribunal has the trust of the disputing parties.

According to A.V. Dicy has three important characteristics of The Rule Of Law, namely: (1) Supremacy of law; (2) Equality before the law; and (3) Due Process of law. ${ }^{28}$ The concept of due process of law is actually found in fundamental rights and the concept of ordered liberty. According to Lawrence M Friedman, that the rule of law can be used in a formal sense and in a material sense. In a formal sense, the rule of law is organized public power. Meanwhile, the role of law in a material sense involves measures of good law and bad law. ${ }^{29}$

Decision of The Political Parties Disputes Tribunal No. 10 of 2017 The case of Simon Kamau vs. Jubilee, is an example of a judge's decision in a party dispute case in Kenya that enforces the party constitution and protects human rights. ${ }^{30}$ Simon Kamau and Samuel Macharia are the Petitioners while the Respondents are Pesta Jubilee, Raphael Tuju, Jane Wanjiru, Joel Irungu. The Petition originated from the Respondent's action to dismiss the Petitioner from his position as Chairman and Secretary of the Party in Murang'a City. The decision is interesting to see the judge's considerations in looking at the enforcement of the party constitution and the protection of human rights.

One of the judges' considerations in the decision of the case ${ }^{31}$ Simon Kamau and Samuel Macharia are the Petitioners must get a fair examination before being dismissed based on their respective positions as chairman and secretary of the Murang'a City branch of the party. This issue has implications for the right to fair administrative action. The requirement for a fair administrative action is one of the fundamental human rights contained in the Bill of Rights of the Constitution of Kenya, 2010. Article 47 of the Constitution requires that everyone who is the subject of an administrative action be served in a fast, efficient, legal, fair and equitable opportunity, procedurally fair. ${ }^{32}$ It requires that an individual must be given a written reason for the action if the basic rights and freedoms of that person are likely to be detrimental as a result of the administrative action. ${ }^{33}$ The 2015 Administration Law has been enacted with the aim of "providing administrative review by the courts or by an independent and impartial tribunal to enforce efficient administration". ${ }^{34}$

Furthermore, in the judge's consideration that the Respondent should have given the Petitioner a reasonable opportunity to be heard and make a defense of the accusations directed against the Petitioner in accordance with the rules and justice and fair procedures. A party member facing administrative action must be entitled to just administrative action. The Court is under a sacred obligation to ensure that the actions of the Defendants comply with the provisions of the 2010 Kenyan constitution and the Law on Fair Administrative Actions of 2015, particularly regarding fair administrative acts. ${ }^{35}$

The consideration in the judge's decision also refers to the Decision of the High Court v Commission on Freedom, Justice and Reconciliation of Former Parte Bete Wambui Mugo (206) eKLR in paragraph 60 which states that:

"The minimum elements of a fair hearing are regulated in Article 47 of the Constitution. I say at least because according to Article 20 of the Constitution, everyone has the right to enjoy fundamental rights and freedoms in the Human Rights Law to the fullest in accordance with the nature of fundamental rights or freedoms and in applying the law, the court is obliged, among others, to develop the law as long as it does not affect the rights or fundamental freedoms and adopting interpretations that are most in favor of upholding

\footnotetext{
${ }^{28}$ Kusnardi dan Harmaily Ibrahim, Hukum Tata Negara Indonesia, Sinar Bakti, Jakarta, 1988, hal. 154

${ }^{29}$ Winahyu Erwiningsih, artikel "Telaah Terhadap Putusan Mahkamah Konstitusi dalam Reformasi Hukum" yang dimuat dalam Jurnal Hukum, Vol.

9, No. 1, Maret 2006: 72-96.

${ }_{30}$ PutusanThe Political Parties Disputes Tribunal No. 10 Tahun 2017.

31 PutusanThe Political Parties Disputes Tribunal No. 10 Tahun 2017.

32 Lihat, Pertimbangan Hakim Bagian 22, Ibid.

33 Lihat, Bagian 23, Ibid

${ }^{34}$ Bagian 24, Ibid

${ }^{35}$ Bagian 32, Ibid
} 
fundamental rights or freedoms. Article 47 of the Constitution states that everyone has the right to administrative action that is prompt, efficient, legal, reasonable and procedurally fair. If a person's fundamental rights or freedoms have been or are likely to be affected by an administrative action, that person has the right to be given a written reason for the action. ${ }^{36}$

In his dictum the judge in the case of Simon Kamau and Samuel Macharia stated: "The Plaintiffs did not get a fair examination as stipulated in the law and the party constitution". The application of the principle of a fair examination (due process of law) is very important to ensure the protection of human rights as stated in the 2010 Kenyan Constitution. The existence of The Political Parties Disputes Tribunal in resolving party disputes is aimed at ensuring that political parties can uphold the constitution, parties and improve the quality of democracy in Kenya

The existing condition of party dispute resolution in Indonesia refers to Law Number 2 of 2011 concerning Political Parties. ${ }^{37}$ In principle, party disputes are resolved internally based on the party constitution by establishing a party court or other designations as party organs. Court judges are appointed through the internal mechanism of each party.

Settlement of party disputes through the party court is not the only way regulated in Law Number 2 of 2011 concerning Political Parties, there are other channels to resolve party disputes through lawsuits to the district court. However, the door for the lawsuit through the district court was only opened after first making efforts to resolve it through the party court. Regarding the decision of the party court regarding management disputes, it is final and binding.

According to M. Yahya Harahap, the judicial power system requires courts to be independent, independent, and not dependent on other parties. ${ }^{38}$ However, the position of the party court as a party organ has caused it to not be independent both in terms of decision making, personal and in terms of administration. The party court from the administrative aspect is facilitated by party administrators both in terms of budget and human resources. This condition has an impact on independence in decision making which creates a conflict of interest.

Likewise, the settlement of party dispute cases through the district court, in practice it does not run effectively which can provide substantive justice to disputing party members. At least from 2011 to 2018 there were 126 dispute cases whose parties were decided by the state court as "premature" applications because there had been no decision by the party court. ${ }^{39}$ This condition causes the disputing party members to not get a place to get justice. On the one hand, it does not get a fair examination through the party court; on the other hand, the court's policy requires that it be investigated first through the party court.

Ideally, according to Gustav Radbruch, judges in deciding cases consider three aspects, namely, justice (gerechtigkeit), legal certainty (rechtsicherheit), and expediency (zwechtmassigkeit). These three aspects need to be considered proportionally in a decision so that it can produce a quality decision and fulfill a sense of justice. ${ }^{40}$ Sudikno Mertokusumo said that the principle of equal treatment before the law requires justice where everyone is equal before the law (equality before the law), everyone should be treated equally. ${ }^{41}$

On another aspect, civil lawsuits to district courts in cases of political party disputes in Indonesia are dominated by the basis of lawsuits against the law. ${ }^{42}$ In legal science there are three categories of actions that qualify as unlawful acts, namely acts against the law because: intentional, without error and due to negligence. ${ }^{43}$ The model of legal responsibility based on the Indonesian Civil Code (KUHPerdata) is responsibility with an element of legality based on Article 1365 BW, responsibility with an element of error in Article 1366 of the Civil Code, responsibility without error is based on Article 1367 of the Civil Code. Although the

\footnotetext{
${ }^{36}$ Lihat, Bagian 32, Ibid

${ }^{38}$ M. Yahya Harahap, Kekuasaan Mahkamah Agung Pemeriksa Kasasi Dan Peninjuan Kembali Perkara Perdata, Sinar Grafika, Jakarta, 2008, hlm. 1.

${ }^{39}$ Sultan Alwan, dkk, Artikel Medico-Legal Update, Oktober-Desember 2020, Vo. 20, No.4, hlm. 1788.

40 Mangesti, Y. A, \& Tanya, B. L, Moralitas Hukum, Genta Publishing, Yogyakarta, 2014, h/m. 74.

${ }^{41}$ Sudikno Mertokusumo, 2002, Mengenal Hukum Suatu Pengantar (cetakan keempat), Liberty, Yogyakarta, hlm. 36

42 Sultan Alwan, Loc. Cit.

${ }^{43}$ Munir Fuady, Perbuatan melawan Hukum, Citra Aditya Bhakti, Bandung, 2002, hlm. 3
} 
interpretation of unlawful acts ((onrechtmatige daad) has been expanded based on the Hoge Raad Decision (cassation) from the case of Arrest Cohen v. Lindenbaum (HR January 31, 1919), however, this does not necessarily apply to cases of political party disputes. Political parties are matters regulated separately in Law Number 2 of 2011 so that they are not subject to the Civil Code in accordance with the principle of lex specialis derogat legi generalis, meaning that laws and regulations that are specific in nature exclude general laws and regulations.

Apart from resolving party disputes through party courts and district courts, party disputes relating to management often lead to lawsuits to the state administrative court. Such conditions have led to the protracted resolution of party disputes in Indonesia. Therefore, the regulation of political party dispute settlement institutions in Indonesia needs to be redesigned to become one door, namely through a special court. The resolution of party disputes that are implemented in Kenya through courts that are special in the judicial power system can be a model that can be adopted in Indonesia.

The purpose of establishing a special court is to make the resolution of party disputes more effective. Normatively, the establishment of a special court does not conflict with the constitution and the law as long as it is within 4 (four) of the courts. According to the author, the appropriate judicial environment is that of the general court environment.

Courts are referred to as the main pillar of law enforcement and justice, and also as a pillar of the nation's civilization process. ${ }^{44}$ The idea of establishing a special court for party disputes in Indonesia is a form of the state's obligation to fulfill, to facilitate the human rights of citizens. ${ }^{45}$ In turn, it can give hope to realize the value of substantive justice for justice seekers.

\section{CONCLUSION}

The existence of The Political Parties Disputes Tribunal as a Kenyan state court with the authority to resolve party disputes, it's very fundamental role is to protect the basic rights of citizens to obtain equality of examination in a fair process (due process of Law), while at the same time playing a role as an effective controller against arbitrary actions of political party administrators, contrary to the constitution.

The resolution of political party disputes in Indonesia involves many institutions, apart from internally, through party courts, externally there are district courts and state administrative courts. The current condition of the institution cannot provide a substantive value of justice to cadres of disputing political parties. So that it is necessary to redesign the institution for resolving political party disputes by establishing a special court in the judicial power system.

\section{REFERENCES}

1. Agus Riwanto, Political Party Law and Election Law in Indonesia: Their Influence on the Implementation of Quality Elections and an Effective Presidential Government System, Thafa Media, Yogyakarta, 2016.

2. Adi Sulistiyono and Isharyanto, The Indonesian Judicial System in Theory and Practice, Prenadamedia Group, Depok, 2018, p.39.

3. Aris Rahmatdi and Pan Mohamad Faiz, Civil Lawsuit against the Law in the Dispute of the Group of Work Party: Study of Decision Number 91/Pdt.G/2015/PN.Jkt.Utr, YUDISIAL Journal, Vol. 14 No. April 1, 2021.

4. Dwi Darojatun Patra Suwito, Legal Aspects of Internal Disputes of Political Parties, Adhi Sarana Nusantara, Jakarta, 2017.

5. H.A Muktie Fadjar, Political Parties in the Development of Indonesian State Administration, In-Trans Publication, Malang, 2008.

\footnotetext{
${ }^{44}$ Komisi Yudisial RI, Kode Etik dan Pedoman Prilaku Hakim, Komisi Yudisial, Jakarta, 2015, hlm. 1-2.

${ }^{45}$ Oliver De Schuttler, International Human Rights Law, New York: Cambridge University Press, 2010, hlm. 242.
} 
6. Firdaus, Constitutional Engineering Design Stability of Democratic Governance and Party Systems, Yrama Widya, Bandung, 2015.

7. Jimly Asshiddiqie, Capita Selekta of Legal Theory of Distributed Writings, FH-UI, Jakarta, 2000.

8. Indonesian Constitution and Constitutionalism, Konstirsi Press, Jakarta, 2005.

9. Kusnardi and Harmaily Ibrahim, Indonesian Constitutional Law, Sinar Bakti, Jakarta, 1988.

10. Laoly, Y. H. (2019). Political party dispute management, an effort to reorganize political institutions in a democratic country, Alvabet, Jakarta, 2019.

11. Mangesti, Y. A, \& Tanya, B. L, Legal Morality, Genta Publishing, Yogyakarta, 2014.

12. Moh. Kusnardi and Bintan R. Sargih, State Science, 2nd Printing Press Media Pranata Style Publisher, Jakarta.

13. Montoha, Indonesia's State of Law after the Amendment of the 1945 Constitution, Kaukaba Publishers, Yogyakarta, 2013.

14. Muhamad Isnu, et al, Reading the Courts of Industrial Relations in Indonesia: Researching Supreme Court Decisions in the Industrial Courts 206-2013, Jakarta Legal Aid Institute, 2014.

15. Muchamad Ali Safa'at, Dissolution of Political Parties Arrangements and Practices of Dissolution of Political Parties in the Struggle of the Republic, Rajawali Pers, Depok, 2017.

16. Mukti Fajar, Yulianto Ahmad, Dualism of Normative and Empirical Legal Research. Yogyakarta: Student Library, 2013 Mustafa Lutfi, M. Iwan Satriawan, Mustafa Lutfi and M. Iwan Satriawan, Minutes of Law on Political Parties in Indonesia, UB Press, Malang, 2016.

17. Munir Fuady, Acts against the Law, Citra Aditya Bhakti, Bandung, 2002.

18. M. Yahya Harahap, Powers of the Supreme Court to Examine Cassation and Judicial Review of Civil Cases, Sinar Graphic, Jakarta, 2008.

19. Indriati Amarini, Effective and Efficient Dispute Resolution through Optimizing Mediation in Courts, Cosmic Law Journal, Vol. 16, No. June 2, 2016.

20. Oly Viana Agustine, Redesign of the Constitutional Mechanism for Dissolution of Political Parties: A Comparative Study of Indonesia and Germany, Journal of STATE LAW: Vol. 9, No. 2, November 2018.

21. Ridwan HR, State Administration Law, UII-Press, Yogyakarta, 2002.

22. Sudikno Mertokusumo, Knowing the Law is an Introduction (fourth printing), Liberty, 2002.

23. Sultan Alwan, et al, Medico-Legal Update Article, October-December 2020, Vo. 20, No.4.

24. Winahyu Erwiningsih, article "A Study of the Constitutional Court Decision in Legal Reform" published in the Legal Journal, Vol. 9, No. 1, March 2006. 